Revista Oficial del Poder Judicial

ÓRGANO DE INVESTIGACIÓN DE LA CORTE SUPREMA DE JUSTICIA DE LA REPÚBLICA DEL PERÚ

Vol. 9, n. ${ }^{\circ} 11$, enero-junio, 2019, 451-453

ISSN versión impresa: 1997-6682

ISSN versión electrónica: 2663-9130

DOI: https://doi.org/10.35292/ropj.u9i11.15

\title{
IX Congreso Internacional sobre Justicia Intercultural, \\ Lima 2018
}

\author{
0 \\ DECLARACIÓN DE LIMA \\ Por una justicia intercultural en base \\ a nuestras raíces y experiencias
}

En Lima, a los veintisiete días del mes de octubre del año 2018, las autoridades de las comunidades campesinas, las autoridades de las comunidades nativas, las autoridades de las rondas campesinas, los líderes y lideresas afroperuanos, los jueces de paz y los jueces ordinarios, reunidos en el IX Congreso Internacional sobre Justicia Intercultural:

1. DECLARAMOS que, a pesar de que el Poder Judicial no cuenta con información suficiente sobre los principales problemas de la población afroperuana respecto de su acceso a la justicia, es evidente la demanda que este colectivo ha expresado al sistema de justicia en búsqueda de cesar los actos de discriminación que vienen sufriendo y ello requiere una respuesta adecuada e inmediata. 
2. RECONOCEMOS que existe un problema de discriminación en el acceso a la justicia de la población afroperuana y que la elaboración de un diagnóstico integral es necesaria para determinar la dimensión estructural del problema, vinculada a condiciones socioeconómicas y geográficas, entre otras.

3. CONSIDERAMOS que, a efectos de incorporar a la población afroperuana en las reflexiones que estos Congresos congregan, resulta necesario identificar los mecanismos para actuar con pertinencia cultural en los casos que la involucren, como parte esencial del desarrollo de la justicia intercultural.

4. RECONOCEMOS que, a pesar de los avances normativos y sociales, aún persiste en el Perú un machismo que mantiene una situación histórica de vulnerabilidad sobre las mujeres. Esto sucede tanto en zonas rurales como urbanas. En el caso particular de las zonas rurales y la aplicación de la jurisdicción especial, no todos los casos de violencia contra la mujer se denuncian.

5. VALORAMOS que ya existen buenas prácticas de coordinación entre la justicia especial y ordinaria. Es verdad, no obstante, que no se da de la misma manera en todas las regiones y que es necesario seguir promoviendo acercamientos positivos a través de espacios de diálogo institucionalizados en los que puedan compartirse e intercambiar experiencias, así como de, por ejemplo, capacitaciones constantes sobre los alcances y competencias de cada jurisdicción, o la promoción del uso de peritajes antropológicos, intérpretes y traductores de lenguas indígenas, como herramientas de carácter básico. En ese sentido, se hace indispensable la creación y difusión de protocolos especializados que sean de fácil comprensión para todos los operadores de ambas instancias de justicia, así como la conformación y formalización de acuerdos de coordinación. 
6. SALUDAMOS la labor de los jueces y juezas de paz como actores clave para la articulación entre la jurisdicción ordinaria y especial y exhortamos apoyar su labor y fortalecimiento como autoridades del sistema de justicia ordinario, así como valorar y reconocer su origen cultural y estrecho vínculo con la justicia impartida por las comunidades campesinas, comunidades nativas o rondas campesinas, así como con el pueblo afroperuano.

Lima, 27 de octubre de 2018 